\title{
Preventive Oral Health Knowledge and Practice in Jeddah,Saudi Arabia
}

\author{
HANAA M. JAMJOOM, BDS, MSc \\ Department of Conservative Dental Sciences, Faculty of Dentistry, \\ King Abdulaziz University, Jeddah, Saudi Arabia
}

\begin{abstract}
Three preventive measures which have been recommended by the American Dental Association include that adults should thoroughly brush and floss their teeth at least once a day and get regular oral health check-ups. The purpose of this study is to assess the oral health knowledge and behaviour patterns among the Saudi Arabian population. 500 subjects were asked to complete a questionnaire which addressed many questions on oral health. All respondents were above 18 years of age. Responses showed that $98.5 \%$ brushed their teeth regularly, $35.2 \%$ used dental floss, and $69.8 \%$ visited the dentist. About $27.6 \%$ of all respondents used all three preventive measures. Miswak was used by $49.2 \%$ of the respondents. The study also showed that television was the most frequently reported source of education for the public on dental hygiene $(60.7 \%$ ). Although $98.5 \%$ of respondents used a dental brush daily, only $27.6 \%$ of the sample used a combination of the three recommended preventive measures. Therefore, there is an urgent need for a government based effort to reinforce knowledge and implementation on proper dental hygiene.
\end{abstract}

Keywords: Oral Health, Knowledge, Practice, Prevention.

\section{Introduction}

Dental problems such as tooth decay, periodontal disease and tooth loss, constitute a major public health problem in the world today ${ }^{[1]}$. In order to prevent oral health problems, the American Dental Association (ADA) and other organisations recommended that adults thoroughly brush and floss their teeth at least once a day and get regular oral

Correspondence \& reprint requests: Dr. Hana Jamjoum, Department of Restorative Treatment,

Faculty of Dentistry, P.O. Box 80209, Jeddah 21589, Saudi Arabia.

Accepted for Publication: 2 April 2000. Received: 15 February 1998 
health check-ups ${ }^{[2,3]}$. Many surveys in different parts of the world have found brushing to be the best way to maintain oral health ${ }^{[4,5,6]}$. Ninety percent of Americans brush at least twice a day ${ }^{[7]}, 97 \%$ of Koreans brush once a day ${ }^{[4]}$, while in India only $69 \%$ of the population brushes their teeth ${ }^{[8]}$.

Other equally important preventive measures apart from brushing include flossing, fluoride, and regular dental visits ${ }^{[9]}$. The need for regular dental check-ups, the use of floss, and fluoride supplements, however, is not appreciated in many parts of the world [5-11]. For example, in Singapore only a small portion of the population visits the dentist each year. A similar observation was found among Americans where only $50 \%$ of the population visits the dentist annually ${ }^{[12]}$.

Among the factors that were found to greatly influence awareness in using dental preventive measures was the media ${ }^{[4,12]}$. This observation might be even more appreciated in developing countries where television constitutes a major role in the daily life of the population as reported in Korea and other Asian countries ${ }^{[6]}$.

In Saudi Arabia, a study on dental care and knowledge of mothers in the city of Medina reported that $62 \%$ brush their teeth twice a day and $41 \%$ use miswak ${ }^{[13]}$. In another study in Riyadh, $80 \%$ of those aged 65-74 years do not brush their teeth. While over half of all the respondents use Miswak ${ }^{[14]}$, more than two thirds of those aged 6574 use Miswak. The earlier study emphasized that the relevant causal factors of dental disease are bacteria, sugar, and improper tooth cleaning. Seventy-five percent of these mothers acknowledge the role of regular dental visits in prevention of dental caries. The dentist, television, family, and friends were the most common sources of dental health information ${ }^{[13]}$.

The purpose of this study was to assess the oral health knowledge and behaviour pattern among the population in Jeddah, Saudi Arabia.

\section{Materials and Methods}

This study included 500 subjects among patients attending general hospitals in Jeddah, Saudi Arabia. The participants were those who were willing to answer an anonymous questionnaire. They were above 18 years of age, and able to understand and answer the questionnaire. Each participant was asked to answer the questionnaire while waiting for his/her appointment. The participant did not receive guidance from the investigator who was waiting in a separate room. An average of 20 minutes was needed to answer all the questions. The questionnaire included demographic information related to the patient's name, age, sex, marital status, income and education. The questionnaire focused on brushing, flossing, dental visits, and educating the public, as shown in Table 1.

Data were entered in an SPSS file, descriptive statistics were completed, and t-tests were used when applicable. All analyses were done using the SPSS statistical package, and $\alpha$ was established at 0.05 throughout the study. 
TABLE 1. Questionnaire

\begin{tabular}{|c|c|c|}
\hline Item & Question & Responses \\
\hline Brushing & Do you brush your teeth? & $\begin{array}{l}\text { 1. Yes } \\
\text { 2. No }\end{array}$ \\
\hline \multirow{2}{*}{ Brushing Frequency } & $\begin{array}{l}\text { How many times do you brush } \\
\text { your teeth? }\end{array}$ & $\begin{array}{l}\text { 1. I don't brush my teeth } \\
\text { 2. Less than once a month } \\
\text { 3. } 1-2 \text { times a month } \\
\text { 4. } 1-2 \text { times a week } \\
\text { 5. Once every } 2 \text { days } \\
\text { 6. Once a day } \\
\text { 7. Twice a day }\end{array}$ \\
\hline & $\begin{array}{l}\text { What do you use with your } \\
\text { tooth brush? }\end{array}$ & $\begin{array}{l}\text { 1. Toothpaste } \\
\text { 2. Powder } \\
\text { 3. Sodium Bicarbonate } \\
\text { 4. I don't use anything } \\
\text { 5. Others }\end{array}$ \\
\hline Flossing & Do you floss? & $\begin{array}{l}\text { 1. Yes } \\
\text { 2. No }\end{array}$ \\
\hline \multirow{2}{*}{ Visiting the dentist } & Do you visit a dentist? & $\begin{array}{l}\text { 1. Yes } \\
\text { 2. No }\end{array}$ \\
\hline & When do you visit a dentist? & $\begin{array}{l}\text { 1. When I am in pain } \\
\text { 2. Every } 6 \text { months } \\
\text { 3. Regularly for check up } \\
\text { 4. I do not go }\end{array}$ \\
\hline & $\begin{array}{l}\text { Other methods to clean your } \\
\text { teeth? }\end{array}$ & $\begin{array}{l}\text { 1. Brush } \\
\text { 2. Miswak } \\
\text { 3. Toothpick } \\
\text { 4. Mouthwash } \\
\text { 5. Don't use anything }\end{array}$ \\
\hline & How to avoid caries? & $\begin{array}{l}\text { 1. Brush regularly } \\
\text { 2. Minimise sweets } \\
\text { 3. Visit the dentist } \\
\text { 4. Use fluoride } \\
\text { 5. All of the above } \\
\text { 6. Don't know }\end{array}$ \\
\hline & $\begin{array}{l}\text { From what source do you get } \\
\text { information about your teeth? }\end{array}$ & $\begin{array}{l}\text { 1. Dentist } \\
\text { 2. Medical Doctor } \\
\text { 3. Newspaper } \\
\text { 4. Magazine } \\
\text { 5. Television } \\
\text { 6. Radio } \\
\text { 7. Friends \& Family } \\
\text { 8. Nurses } \\
\text { 9. Books } \\
\text { 10. Schools } \\
\text { 11. Pamphlets }\end{array}$ \\
\hline
\end{tabular}




\section{Results}

In the present study, the questionnaire was given to 500 subjects. Of the 500 subjects, 488 responded to questions about age, and 491 to each of the other demographic variables. Demographic characteristics of the sample are presented in Table 2. Approximately $219(44.6 \%)$ were males, $272(55.4 \%)$ were females. Two-hundred and sixty-nine $269(55.1 \%)$ were 18-29 years of age, and Saudi nationality was reported for $295(60.1 \%)$ of the sample. In terms of level of education achieved by respondents, $225(45.8 \%)$ reported high school education, $65(13.2 \%)$ primary school, and the remaining $201(40.9 \%)$ achieved college level education. A total of 463 subjects' questionnaires regarding oral hygiene control were completed, and are used in related statistical analyses.

TABLE 2. Demographic characteristics of the sample

\begin{tabular}{|c|c|c|c|}
\hline Correlates & Categories & N & Percentage \\
\hline \multirow{2}{*}{ Age } & $18-29$ & 269 & $55.1 \%$ \\
$(\mathrm{n}=488)$ & $30-39$ & 114 & $23.4 \%$ \\
& 40 or above & 105 & $21.5 \%$ \\
\hline Gender & Male & 219 & $44.6 \%$ \\
$(\mathrm{n}-491)$ & Female & 272 & $55.4 \%$ \\
\hline Nationality & Saudi & 295 & $60.1 \%$ \\
$(\mathrm{n}=491)$ & Non-Saudi & 196 & $39.9 \%$ \\
\hline \multirow{2}{*}{ Education } & Primary & 65 & $13.2 \%$ \\
$(\mathrm{n}=491)$ & High School & 225 & $45.8 \%$ \\
& College & 201 & $40.9 \%$ \\
\hline
\end{tabular}

\section{Brushing}

Table 3 presents data for use of brushing as an oral hygiene method. Approximately 98.5\% of respondents brushed their teeth regularly. This percentage included not only those who brush, but also those who brush and floss and those who visit the dentist in combination with brushing. However, only $36.8 \%$ brushed twice a day, $19 \%$ once a day and $21 \%$ more than two times a day. Approximately $93.7 \%$ used toothpaste with the brush, and the remaining $6.3 \%$ used other methods of cleaning.

\section{Flossing}

Table 3 also presents data for flossing. In this sample no subject used floss as the only means of cleaning but $35.2 \%$ of the respondents flossed their teeth using brushing and dental visits as other means of oral health care.

\section{Dental Visits}

Approximately $69.8 \%$ of the respondents, as seen in Table 3, visit the dentist as a preventive measure. Some of the respondents also use brushing and flossing as other means of prevention. Only $1.5 \%$ of the respondents use the dental visit as the only 
means of oral health care. From the $69.8 \%$ who visit the dentist, only $15 \%$ go for regular dental check-ups every six months, while $69 \%$ visit the dentist only when they have pain.

\section{Correlation between Brushing, Flossing, and Dental Visits}

Table 3 shows that only $7.6 \%$ of the participants brush and floss, and no one reports the use of floss as the only preventive measure. Approximately $27.6 \%$ of all respondents use all three preventive measures. The largest groups of subjects $(40.6 \%)$ brush and visit the dentist.

TABLE 3. Frequency data for methods of oral hygiene control.

\begin{tabular}{|l|c|c|c|}
\hline Methods of Oral Hygiene & Number & Percentage & Cumulative Percentage \\
\hline Brush Only & 105 & 22.7 & 22.7 \\
\hline Floss Only & 0 & 0.0 & 22.7 \\
\hline Dental Visit Only & 7 & 1.5 & 24.2 \\
\hline Brush \& floss & 35 & 7.6 & 31.8 \\
\hline Brush \& dental visit & 188 & 40.6 & 72.4 \\
\hline Floss \& dental visit & 0 & 0.0 & 72.4 \\
\hline Brush, floss, \& dental visit & 128 & 27.6 & 100.0 \\
\hline \multicolumn{1}{c|}{ Total } & 463 & & \\
\hline
\end{tabular}

The opinions of the respondents on how to avoid caries were very promising. As seen in Table 4, 36.7\% reported that brushing regularly is effective while $54.9 \%$ were aware that brushing, minimizing sweets, visiting the dentist and the use of fluoride are all effective means of avoiding caries.

TABLE 4. The percentage of opinions on how to avoid caries based on a sample of 463 subjects.

\begin{tabular}{|l|c|c|}
\hline \multicolumn{1}{|c|}{ Correlates } & $\mathrm{n}$ & Percentage (\%) \\
\hline Brush regularly & 170 & 36.7 \\
\hline Minimise sweets & 80 & 17.3 \\
\hline Visit the dentist & 59 & 12.7 \\
\hline Uses fluoride & 20 & 4.3 \\
\hline All of the above & 254 & 54.9 \\
\hline Don't know & 19 & 4.1 \\
\hline
\end{tabular}


Table 5 shows that the most effective source of dental hygiene was television as reported by $60.7 \%$ of the respondents, and $46.7 \%$ recorded that the dentist was an in fluential source.

TABLE 5. The percentage of the effective sources of oral health information in a sample of 463 subjects.

\begin{tabular}{|l|c|c|}
\hline \multicolumn{1}{|c|}{ Sources } & Numbers & Percentage (\%) \\
\hline Television & 281 & 60.7 \\
\hline Dentist & 216 & 46.7 \\
\hline Magazine & 133 & 28.7 \\
\hline Newspaper & 95 & 20.3 \\
\hline Family \& Friends & 83 & 17.9 \\
\hline Radio & 41 & 8.9 \\
\hline Medical Doctor & 15 & 3.2 \\
\hline Nurses, Books, School, Pamphlets & 34 & 7.3 \\
\hline
\end{tabular}

Table 6 shows that the respondents also used other methods of oral hygiene, including miswak (49.2\%), toothpick (35.6\%), and mouthwash $(31.7 \%)$, with many of the subjects using a combination of these methods. However, $18.4 \%$ reported not using any of the methods for oral hygiene control.

TABLE 6. The percentage of other methods used for oral hygiene in a sample of 463 subjects.

\begin{tabular}{|l|c|c|}
\hline \multicolumn{1}{|c|}{ Other Methods } & $\mathbf{n}$ & Percentage (\%) \\
\hline Miswak & 228 & 49.2 \\
\hline Toothpick & 165 & 35.6 \\
\hline Mouthwash & 147 & 31.7 \\
\hline Don't use anything & 85 & 18.4 \\
\hline
\end{tabular}

\section{Discussion}

The main purpose of this study was to assess knowledge and practice of residents in Jeddah towards preventive oral health measures. A majority of the participants were 18-29 year old Saudi females. Brushing was the most commonly used method of teeth cleaning, followed by the toothpick, and miswak methods. A surprisingly small percentage reported using dental floss, whereas visiting the dentist was more common. The importance of regular brushing as oral health prevention is well-documented ${ }^{[4,5,8]}$. In the United States, $90 \%$ of a studied group reported brushing their teeth twice a day [5-16]. In a study on the Saudi population, a much lower percentage of participants brushed daily $(33 \%)$ and those were above 40 years old ${ }^{[14]}$. In the same study, $80 \%$ of the participants over 65 did not clean their teeth at all. It seems that age plays a major 
role in motivation in adopting regular brushing practice. The use of dental floss as an oral hygiene measure varies greatly in different reports ${ }^{[16-18]}$. However, there is generally a failure in the use of dental floss as a preventive tool. The low percentage of participants who use floss in this study emphasizes the urgent need for educating and motivating the public to use this efficient method for oral health care.

Interestingly, $69 \%$ of participants reported visiting the dentist only when they have pain. This is another gap in public education regarding the crucial role of regular dental check-ups in preventing and detecting dental diseases. The use of miswak as a means of tooth-cleaning was reported by half of the participants. This rate is probably increased by the high number of Saudis in the study since miswak is locally used on a large scale among Saudis. Miswak in general has shown high potential in removing plaque accumulation on teeth which is one of the causative factors for caries and periodontal disease.

The correlation of knowledge between the three major means of prevention as analyzed in Table 3 showed that a small percentage of the participants perform all three major prevention procedures even though they are aware that brushing, minimizing sweets, visiting the dentist, and fluoride are all together the best methods of avoiding caries.

It appears that the best source of education is television. Our results agreed with Malaysian $^{[6]}$ and Korean ${ }^{[4]}$ studies which showed television to be the best source of information as it is seen by all the members of the family.

This study showed that the majority of the participants knew about brushing as a primary means of good oral health but they lacked knowledge of the other preventive measures. It is imperative that the media should be utilized to educate and spread knowledge of proper dental care and prevention of dental disease.

In conclusion, the results of this study show limited knowledge on prevention and preventive dental behaviour. Brushing of teeth by almost the entire population is the most commonly practised method, yet only a small percentage used floss, and the dentist is visited primarily for pain relief. A small percentage of subjects brushed their teeth twice a day, and even a smaller percentage performed all three means of prevention to maintain good oral health. The television and the dentist were the two best sources of information for educating the public.

\section{References}

[1] World Heath Organization Oral Health Survey. Basic Methods (3rd edn., Geneva) 1987.

[2] No authors listed. Wake up to prevention for the smile of a lifetime. J Am Dent Assoc 1988; 116(5): 6G-13G.

[3] No authors listed. Rx for sound teeth, National Institutes of Health 1991; 91: 3245.

[4] Paik DI, Moon HS, Horowitz AM, Gift HC, Jeong KL, Suh SS. Knowledge of and practice related 
to caries prevention among Koreans. J Pub Health Dent 1990; 54(4): 205-210.

[5] Soh G. Understanding prevention of dental caries and gum disease in the Singapore population. Odontostomatol Trop 1992 ;15(1): 25-29.

[6] Soh G. Understanding prevention of dental caries and gum disease in an Asian Community. J Ir Dent Assoc 1991; (37)1: 6-9.

[7] No authors listed. Survey of family tooth brushing practices. Bureau of Dental Health Education. Bureau of Research \& Statistics. J Am Dent Assoc 1966; 72(6): 1489-1491.

[8] Tewari A, Guba K, Goyal A. Evaluation of existing status of knowledge practice and attitude towards health of rural communities of Horyana, India. J Indian Soc Pedo Prevent Dent 1991; 9: 21-30.

[9] Newburn E. Preventing dental caries:breaking the chain of transmission. J Am Dent Assoc 1992; 123(6): 55-59.

[10] Soh G. Racial differences in perception of oral health and oral health behaviours in Singapore. Int Dent J 1992; 42(4): 234-240.

[11] Craig T, Montague JL. Family oral health survey. J Am Dent Assoc 1976; 92: 326-332.

[12] Bonito AJ, Ionacchione $\mathbf{V}$, Jones $\mathbf{S}$, and Stuart $\mathbf{C}$. The impact of prepaid dental care on dental service utilisation and oral health. Research Triangle Park, North Carolina: Research Triangle Institute 1986.

[13] Al-Tamimi S. Oral health situation of children, mothers and school teachers in Saudi Arabia. Tandlaegebladet 1997; 101(12): 662-663.

[14] Guile E, Al-Shammary A, El-Backly M. Oral health survey of Saudi Arabia: oral health knowledge, attitude and practice among adults. Saudi Dent J 1996; 8: 6.

[15] Esa R, Razak IA, Jalalludin RL. Cross cultural variation in dental knowledge among antenatal mothers. Odonto-Stomtologie Trop 1992; 15(1): 19-23.

[16] Al Shammery AR, Guile EE, Backly M. The prevalence of caries in primary school children in Saudi Arabia. Comm Dent Oral Epidemiol 1990; 18(6): 320-321.

[17] Ronis D, Lang P, Farghaly M, Ekdhal S. Preventive oral health behaviours among Detroit area resdents. J Dent Hyg 1994; 88: 123-130.

[18] Lo EC, Schwartz E. Attitude toward dentist and the dental care system among the middle aged and the elderly in Hong Kong. Comm Dent Oral Epidemiol 1994; 22: 369-373. 


\title{
الوعي والسلوك للوسائل الوقائية لصحة

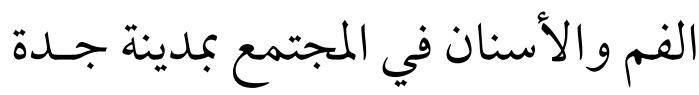 المملكة العربية السعودية.
}

\author{
هناء محمد جمجحوم

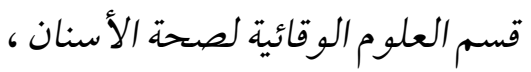

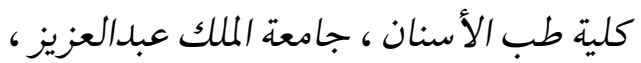 \\ جـــــة - المملكة العربية السعودية.
}

المستـخلص. اعتـمد الاتحـاد الأمريكي لطب الأسنان ثلاث وسـائل وقائية لأسنان البالغين وذلك بإستعمال الفرشاة وخيط الأسنان مرة يومياً

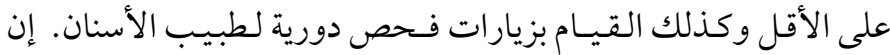

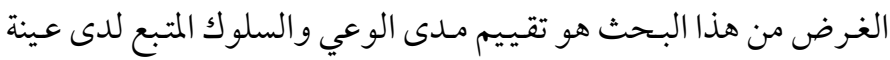

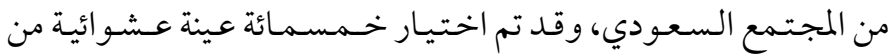

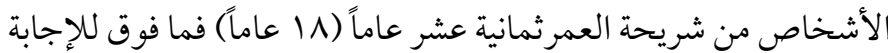

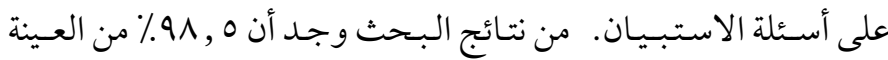

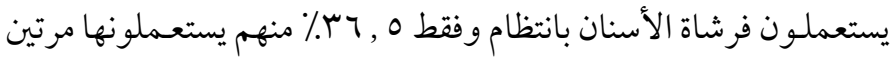

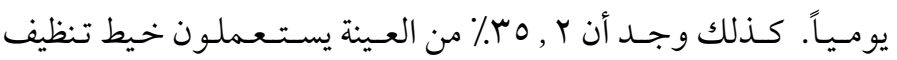

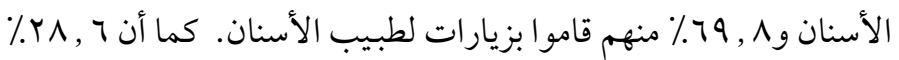

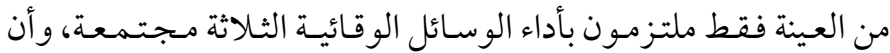

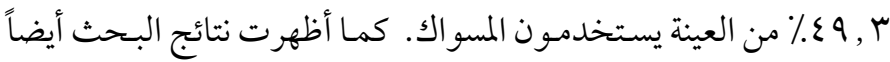

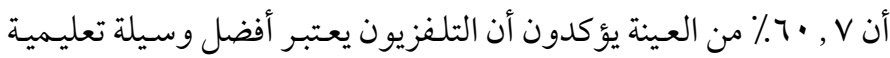
بالنسبة لهم. 